\title{
Studi Meta-Analisis Kemampuan Pemecahan Masalah Matematika
}

\author{
Sri Anandari Safaria ${ }^{1)}$; Andi Reski²); Tandri Patih' ${ }^{1)}$ \\ 1) Dosen Tadris Matematika, Fakultas Tarbiyah dan Ilmu Keguruan (FTIK), Institut Agama Islam Negeri (IAIN) \\ Kendari; \\ 2) Alumni Tadris Matematika, FTIK, IAIN Kendari \\ Email Korespondensi: srianandarisafaria@gmail.com
}

\begin{abstract}
s
This study aims to determine the ability to solve mathematical problems through meta-analysis in the Southeast Sulawesi region. The method in this study uses meta-analysis. Data on mathematical problem solving abilities were obtained from data from previous research, totaling 12 in the form of 6 journals, 5 theses, and 1 thesis. The meta-analysis procedures used in this study are: 1) determining the research domain to be summarized, 2) selecting the types of publications collected, 3) collecting research results, 4) recording research data, 5) calculating the effect size of each result. research. The results showed that students' mathematical problem solving abilities in terms of education level at the junior high school level were more likely to develop mathematical problem solving abilities than high school students. students' mathematical problem solving abilities in terms of the research year tend to be unstable every year, and students' mathematical problem solving abilities in terms of learning models/approaches have not been maximized.
\end{abstract}

Keywords: Meta-Analysis, Effect Size, Mathematical Problem Solving

\begin{abstract}
Abstrak
Penelitian ini bertujuan untuk mengetahui kemampuan pemecahan masalah matematika melalui meta-analisis di wilayah Sulawesi Tenggara. Metode dalam penelitian ini mengggunakan meta-analisis. Data kemampuan pemecahan masalah matematika diperoleh dari data hasil penelitian sebelumnya berjumlah 12 berupa 6 jurnal, 5 skripsi, dan 1 tesis. Prosedur meta-analisis yang digunakan dalam penelitian ini yaitu: 1) menetapkan domain penelitian yang akan dirangkum, 2) memilih jenis publikasi yang dikumpulkan, 3) mengumpulkan hasil penelitian, 4) mencatat data-data penelitian, 5) menghitung effect size dari setiap hasil penelitian. Hasil penelitian menunjukkan bahwa kemampuan pemecahan masalah matematika siswa ditinjau dari jenjang pendidikan pada tingkatan SMP lebih cenderung dilakukan pengembangan kemampuan pemecahan masalah matematika dibandingkan pada siswa SMA, kemampuan pemecahan masalah matematika siswa ditinjau dari wilayah penelitian lebih banyak dilakukan pengembangan di kota Kendari daripada di daerah lain, kemampuan pemecahan masalah matematika siswa ditinjau dari tahun penelitian cenderung tidak stabil setiap tahunnya, dan kemampuan pemecahan masalah matematika siswa ditinjau dari model/pendekatan pembelajaran belum maksimal.
\end{abstract}

Kata Kunci: Meta-Analisis, Effect Size, Pemecahan Masalah Matematika

\section{PENDAHULUAN}

Matematika suatu ilmu yang dapat melatih kemmapuan berpikir dan memberikan kontribusi dalam penyelesaian masalah sehari-hari (Agus, 2019). Namun, bagi siswa matematika adalah sesuatu hal yang kurang menarik, sulit untuk dipahami, serta siswa merasa bingung dengan penyelesaian masalah yang harus digunakan (Patih et al., 2020). Tujuan belajar matematika di sekolah salah satunya adalah agar siswa dapat memiliki keterampilan pemecahan masalah matematika yang dapat dipalikasikan dalam kehidupan (Islamiah \& Purwaningsih, 2018).

Kemampuan pemecahan masalah matematika adalah bagian aktivitas matematika yang begitu penting untuk dikembangkan oleh guru maupun siswa, tetapi kemampuan berpikir ini bagi guru masih dianggap sulit untuk diajarkan dan sulit dipelajari menurut siswa (Kurnia, Dedyerianto, Inah, \& Patih, 2020; Setiawan \& Harta, 2014). Kemampuan pemecahan masalah matematika berhubungan dengan kemampuan representasi matematis secara mutlak karena representasi yang tepat adalah langkah mudah untuk menyelesaikan masalah. Dalam pembelajaran matematika proses penyelesaian masalah sesutu hal yang sangat ditekankan (Kadir, 2017). Proses pemecahan masalah matematika berbeda dengan proses menyelesaikan soal matematika. Jika suatu soal matematika dapat segera ditemukan cara menyelesaikannya, maka soal tersebut tergolong pada soal rutin dan soal itu bukan merupakan suatu masalah (Hidayat \& Sariningsih, 2018).

Kemampuan pemecahan masalah matematis merupakan salah satu kemampuan berpikir tingkat tinggi yang harus dikembangkan dan dilatihkan dengan baik terhadap siswa. Namun, fakta mengungkapkan kemampuan pemecahan masalah matematis siswa masih tergolong rendah. Siswa lebih terbiasa menjawab soal rutin sehingga merasa kesulitan jika diberi soal yang tidak biasa (Sangila, Safaria, Rahayu, \& Asran, 2019). Fakta lain yang menunjukan rendahnya kemampuan pemecahan masalah dapat dilihat dari hasil tes yang 
diselenggarakan oleh Programme for Internasional Student Assessment (PISA) menyatakan rata-rata nilai siswa Indonesia adalah 386 dan menempati peringkat ke- 62 dari 69 negara peserta (Haryanti, 2015). Hal ini juga didukung oleh hasil keikutsertaan Indonesia dalam Treads in International Matematics and Science Study (TIMSS) mengatakan bahwa, salah satu indikator yang dinilai dalam TIMSS adalah kemampuan dalam memecahkan masalah non rutin (Islamiah \& Purwaningsih, 2018)

Pemecahan masalah dalam matematika dapat berbentuk soal cerita. Dalam pembelajaran matematika, jika diberikan soal cerita siswa menganggap lebih sulit untuk mencari solusi penyelesaiannya daripada soal tentang bilangan. Penyelesaian masalah tentang soal cerita siswa terlebih dahulu dituntut untuk memahami dengan baik apa yang diketahui dan apa yang ditanyakan. Selanjutnya, siswa dapat membuat model matematika dan menyatakan rumus yang sesuai kemudian melakukan prosedur penyelesaian yang sesuai dan benar (Zaif, Sunardi, \& Diah, 2013). Pemecahan masalah didefinisikan sebagai suatu usaha untuk mencari solusi dari suatu permasalahan yang muncul dalam kehidupan sehari-hari (Bishop \& Polya, 1991). Prosedur dalam pemecahan masalah matematika mengacu pada empat langkah yang telah dikemukakan oleh Polya yaitu memahami masalah yang berarti kemampuan mengidentifikasi unsur-unsur yang diketahui dan ditanyakan, merencanakan penyelesaian masalah, melaksanakan rencana penyelesaian yang berarti mejalankan prosesdu penyelesaian umtuk mendapatkan penyelesaian, dan menafsirkan solusi yang diperoleh (Nugroho \& Dwijayanti, 2019).

Kebaruan pada penelitian ini yaitu penelitian berfokus pada kemampuan pemecahan masalah matematika ditinjau dari jenjang pendidikan, wilayah penelitian, tahun penelitian, dan model/pendekatan pembelajaran melalui meta-analisis pada hasil penelitian yang telah dipublikasi dan tidak dipublikasi diwilayah Sulawesi Tenggara. Meta analisis mengkaji beberapa hasil penelitian dalam ranah yang sejenis dengan cara merangkum data penelitian, mereview dan menganalisis data penelitian dari beberapa hasil penelitian yang sudah ada sebelumnya (Anugraheni, 2018). Penelitian ini bertujuan untuk mengetahui pengaruh kemampuan pemecahan masalah matematika ditinjau dari jenjang pendidikan, mengetahui pengaruh kemampuan pemecahan masalah matematika ditinjau dari wilayah penelitian, mengetahui pengaruh kemampuan pemecahan masalah matematika ditinjau dari tahun penelitian, dan mengetahui pengaruh kemampuan pemecahan masalah matematika ditinjau dari model/metode/pendekatan penelitian.

\section{METODE PENELITIAN}

Jenis penelitian yang digunakan dalam penelitian ini yaitu penelitian survey yang bersifat deskripsif. Penelitian ini dilaksanakan pada 2 perguruan tinggi di Sulawesi Tenggara yakni Institut Agama Islam Negeri (IAIN) Kendari dan Universitas Haluoleo. Pengumpulan data dalam penelitian ini dilakukan dengan menelusuri jurnal, skripsi dan tesis melalui internet maupun koleksi jurnal perpustakaan. Penelusuran jurnal dilakukan melalui Google Cendekia. Dari hasil penelusuran kemampuan pemecahan masalah matematika yang memenuhi kriteria yaitu 12 karya ilmiah yang terdiri dari 6 jurnal, 5 skripsi dan 1 tesis.

Prosedur penelitian yang dilakukan mengacu pada tahapan meta analisi oleh (Glass, 1982) yaitu: 1) menetapkan domain penelitian yang akan dirangkum, 2) memilih jenis publikasi yang dikumpulkan, 3) mengumpulkan hasil penelitian, 4) mencatat data-data penelitian, 5) menghitung effect size dari setiap hasil penelitian (Nugroho, Dwijayanti, \& Atmoko, 2020). Teknik analisis data bertujuan: 1) mengetahui besar pengaruh (effect size) kemampuan pemecahan masalah matematika berdasarkan jenjang pendidikan SD, SMP, dan SMA, 2) mengetahui besar pengaruh (effect size) kemampuan pemecahan masalah matematika berdasarkan wilayah yaitu Kota Kendari, Kabupaten Muna, dan Kabupaten Buton Utara, 3) mengetahui besar pengaruh (effect size) kemampuan pemecahan masalah matematika berdasarkan tahun dari tahun 2014-2020, 4) mengetahui besar pengaruh (effect size) kemampuan pemecahan masalah matematika berdasarkan model/metode/pendekatan. Formula Effect size yang digunakan dalam penlitian ini sebagai berikut (Kadir, 2017):

Dimana:

$$
\Lambda=\frac{\bar{X}_{E}-\bar{X}_{k}}{S_{K}}
$$

$\Lambda=$ besar pengaruh (effect size)

$\bar{X}_{E}=$ rata-rata kelompok eksperimen

$\bar{X}_{k}=$ rata-rata kelompok kontrol

$S_{K}=$ simpangan baku kelompok kontrol

Kriteria yang digunakan untuk mengintepretasikan effect size mengacu pada Gravetter dan Wallnau) sebagai berikut:

Efek kecil $\quad: 0.01<\Lambda \leq 0.09$

Efek sedang : $0.09 \quad<\Lambda \leq 0.25$

Efek besar $\quad: \quad \Lambda>0.25$ 


\section{HASIL DAN PEMBAHASAN}

\section{Kemampuan Pemecahan Masalah Ditinjau dari Jenjang Pendidikan}

Data kemampuan pemecahan masalah matematika berdasarakan hasil penelusuran diperoleh 6 jurnal, 5 skripsi, dan 1 tesis yang memenuhi kriteria untuk dilakukan analisis. Kemampuan pemecahan masalah matematika melalui meta analisis dilakukan dengan menghitung effect size dengan melihat rata-rata kelas eksperimen $\bar{X}_{E}$, rata-rata kelas kontrol $\bar{X}_{k}$ dan standar deviasi kelas kontrol $S_{K}$. Data hasil penelitian tersebut merupakan hasil penelitian yang dipublikasikan dan yang tidak dipublikasikan dari tahun 2014-2020 yang berada di Universitas Haluoleo Sulawesi Tenggara. Berikut adalah tabel data hasil perhitungan effect size ditinjau dari jenjang pendidikan.

Tabel 1. Nilai Effect Size Kemampuan Pemecahan Masalah Ditinjau dari Jenjang Pendidikan

\begin{tabular}{llrrrrll}
\hline $\begin{array}{l}\text { Kode } \\
\text { Data }\end{array}$ & $\begin{array}{c}\text { Jenjang } \\
\text { Pendidikan }\end{array}$ & $\overline{\boldsymbol{X}}_{\boldsymbol{E}}$ & $\overline{\boldsymbol{X}}_{\boldsymbol{k}}$ & \multicolumn{1}{c}{$\boldsymbol{S}_{\boldsymbol{K}}$} & $\boldsymbol{\Lambda}$ & Kategori & $\begin{array}{c}\text { Rata-Rata } \\
\text { Effect size }\end{array}$ \\
\hline S1 & SMP & 64,07 & 58,78 & 13,68 & 0,39 & Besar & \\
S2 & SMP & 57,44 & 43,22 & 16,94 & 0,84 & Besar & \\
S3 & SMP & 75,24 & 64 & 10,49 & 1,07 & Besar & \\
J2 & SMP & 44,2 & 29,79 & 10,47 & 1,38 & Besar & \\
S4 & SMP & 59,42 & 54,81 & 12,75 & 0,36 & Besar & 0,77 (Besar) \\
S5 & SMP & 51,41 & 46,94 & 13,36 & 0,33 & Besar & \\
S6 & SMP & 55 & 43,91 & 12,82 & 0,87 & Besar & \\
J5 & SMP & 73,27 & 59,39 & 11,38 & 1,22 & Besar & \\
J6 & SMP & 65,22 & 55,22 & 20,07 & 0,5 & Besar & \\
S8 & SMA & 67,77 & 60,96 & 12,88 & 0,53 & Besar & \\
J7 & SMA & 90,65 & 82,25 & 0,76 & 11,05 & Besar & 3,90 (Besar) \\
J8 & SMA & 58,91 & 55,81 & 23,83 & 0,13 & Sedang & \\
\hline
\end{tabular}

Berdasarkan hasil perhitungan effect size ditinjau dari jenjang pendidikan pada Tabel 1 ditemukan nilai effect size terbesar pada kode $\mathrm{J} 7$ dan nilai effect size terkecil pada kode J8. Pada jenjang SMP nilai effect size terbesar pada kode J2 dan effect size terkecil pada kode S5. Sedangkan pada jenjang SMA nilai effect size terbesar pada kode $\mathrm{J} 7$ dan nilai effect size terkecil pada kode J8 kategori sedang. Nilai rata-rata effect size pada jenjang SMP sebesar 0,77 kategori besar dan rata-rata effect size pada jenjang SMA sebesar 3,90 juga berada pada kategori besar.

Hasil analisis effect size pada jenjang pendidikan SMP dengan menggunakan 9 hasil penelitian pada jenjang SMP dan 3 hasil penelitian pada jenjang SMA diperoleh effect size pada kategori besar. Hal ini menunjukan bahwa penerapaan suatu model pembelajaran tertentu berpengaruh terhadap kemampuan pemecahan masalah matematika siswa SMP maupun siswa SMA. Hal ini sejalan dengan penelitian yang dilakukan oleh (Rinaldi \& Afriansyah, 2019) bahwa kemampuan pemecahan masalah matematika siswa SMP mengalami peningkatan dengan menerapkan model pembelajaran Problem Based Learning. Begitupula dengan penelitian oleh (Liyu, Lambertus, \& Yasin, 2016) dalam yang mengemukakan bahwa kemampuan pemecahan masalah matematika siswa SMA yang diajar dengan pendekatan metakognisi lebih baik daripada siswa yang diajar dengan pendekatan pembelajaran biasa. Sehingga dapat dikatakan model/ pendekatan yang melibatkan keaktifan siswa dan siswa membangun sendiri pengetahuannya sangat efektif digunakan dalam mengembangkan kemampuan berpikir matematika terkhusus dalam kemampuan pemecahan masalah matematika baik pada jenjang SMP maupun SMA. Pada kedua jenjang pendidikan ini siswa memerlukan kemampuan pemecahan masalah dalam menganalisis dan menyelesaikan suatu persoalan matematika yang diberikan oleh guru dengan mengikuti langkah pemecahan masalah matematika yang tepat.

\section{Kemampuan Pemecahan Masalah Ditinjau dari Wilayah Penelitian}

Kemampuan pemecahan masalah matematika melalui meta analisis dilakukan dengan menghitung effect size dengan melihat rata-rata kelas eksperimen $\bar{X}_{E}$, rata-rata kelas kontrol $\bar{X}_{k}$ dan standar deviasi kelas kontrol $S_{K}$. Data hasil penelitian tersebut merupakan hasil penelitian yang dipublikasikan dan yang tidak dipublikasikan dari tahun 2014-2020 yang berada di Universitas Haluoleo Sulawesi Tenggara. Data hasil penelitian yang dianalsis berada pada 3 wilayah di Sulawesi Tenggara yakni Kota Kendari, Kabupaten Muna, dan Kabupaten Buton Utara. Nilai effect size kemampuan pemecahan masalah matematika ditinjau dari wilayah penelitian dapat dilihat pada tabel 2 berikut. 
Tabel 2. Nilai Effect Size Kemampuan Pemecahan Masalah Ditinjau dari Wilayah Penelitian

\begin{tabular}{lllllll}
\hline Kode Data & Wilayah & $\overline{\boldsymbol{X}}_{\boldsymbol{E}}$ & $\overline{\boldsymbol{X}}_{\boldsymbol{k}}$ & $\boldsymbol{S}_{\boldsymbol{K}}$ & \multicolumn{1}{c}{$\boldsymbol{\Lambda}$} & Kategori \\
\hline S1 & Kendari & 64,07 & 58,78 & 13,68 & 0,39 & Besar \\
S2 & Kendari & 57,44 & 43,22 & 16,94 & 0,84 & Besar \\
S4 & Kendari & 59,42 & 54,81 & 12,75 & 0,36 & Besar \\
S5 & Kendari & 51,41 & 46,94 & 13,36 & 0,33 & Besar \\
S6 & Kendari & 55 & 43,91 & 12,82 & 0,87 & Besar \\
J5 & Kendari & 73,27 & 59,39 & 11,38 & 1,22 & Besar \\
J6 & Kendari & 65,217 & 55,217 & 20,069 & 0,5 & Besar \\
S8 & Kendari & 67,77 & 60,96 & 12,88 & 0,53 & Besar \\
J7 & Kendari & 90,65 & 82,25 & 0,76 & 11,05 & Besar \\
J8 & Muna & 58,91 & 55,81 & 23,83 & 0,13 & Sedang \\
S3 & Muna & 75,24 & 64 & 10,49 & 1,07 & Besar \\
J2 & Buton Utara & 44,2 & 29,79 & 10,47 & 1,38 & Besar \\
\hline
\end{tabular}

Berdasarkan hasil perhitungan effect size ditinjau dari wilayah penelitian pada Tabel 2 ditemukan di Kota Kendari nilai effect size terbesar pada kode $\mathrm{J} 7$ dan nilai effect size terkecil pada kode S5 yang berada pada kategori besar. Pada wilayah Kabupaten Muna nilai effect size terbesar pada kode S3 yang berarti kategori besar dan effect size terkecil pada kode J8 yang berada pada kategori sedang. Dan wilayah penelitian Kabupaten Buton Utara yang memilki effect size 1,38 berada pada kategori besar.

Hasil analisis effect size pada wilayah penelitian dengan menggunakan 9 hasil penelitian di Kota Kendari, 2 hasil penelitian di Kabupaten Muna, dan 1 hasil penelitian di Kabupaten Buton Utara. Hal ini menunjukan bahwa penerapaan suatu model pembelajaran tertentu berpengaruh terhadap kemampuan pemecahan masalah matematika siswa SMP maupun siswa SMA. Dari ketiga wilayah penelitian tersebut kemampuan pemecahan masalah matematika siswa ditinjau dari rata-rata effect size berada pada kategori efek besar.

Hasil analisis effect size yang dilakukan pada wilayah penelitian ditemukan kode $\mathrm{J} 7$ effect size dari ketiga wilayah penelitian yakni di Kota Kendari. Hal ini dikarenakan pendekatan yang digunakan dalam mengembangkan kemampuan pemecahan masalah matematika adalah pendekatan metakognisi. Hal ini sejalan dengan penelitian yang dilakukan oleh (Liyu et al., 2016)bahwa siswa yang mendapat pembelajaran pendekatan metakognisi kemampuan pemecahan masalah meningkat. Temuan ini mengungkap bahwa wilayah penelitian sangatlah berpengaruh terhadap variabel kemampuan pemecahan masalah yang kita teliti karena sekolah tersebut salah satu sekolah unggulan di wilayah kota Kendari yaitu SMA Negeri 4 Kendari yang memiliki prestasi akademik yang baik.

Berdasarkan analisis effect size pada wilayah Kabupaten Muna diperoleh 2 hasil penelitian. Hasil penelitian dengan kode J8 berada pada kategori efek sedang dan kode S3 berada pada kategori efek besar. Penelitian ini tepatnya dilakukan di SMP Negeri 2 Watopute pada siswa kelas VIII dengan menggunakan pengaruh strategi konflik kognitif setting kooperatif terhadap kemampuan pemecahan masalah. Penerapan model ini memberikan perubahan positif terhadap pembelajaran matematika. Siswa mulai berinisiatif untuk terlibat aktif dalam kelompok serta antusias bertanya selama proses pembelajaran. Lingkungan sekolah mendukung aspek kemampuan pemecahan masalah matematika yang diteliti karena terlihat dari antusias siswa menyambut pembelajaran dan sekolah ini telah terakreditasi A.

Berdasarkan analisis effect size pada wilayah Kabupaten Buton Utara diperoleh nilai effect size pada kategori besar. Penelitian ini dilakukan di SMP Negeri 1 Kulisusu Utara pada kelas VIII. Hasil penelitian menunjukkan ada pengaruh yang signifikan terhadap kemampuan pemecahan masalah matematis siswa yang mendapat pembelajaran problem posing dibandingkan dengan siswa yang mendapat pembelajaran langsung. Sekolah ini sudah terkareditasi A sehingga mendukung indikator kemampuan pemecahan masalah yang sedang dikaji.

Berasarkan wilayah penelitian kota Kendari termasuk wilayah terbaik dari hasil penelitian tentang kemampuan pemecahan masalah matematika. Hal ini dikarenakan perkembangan teknologi informasi dan komunikasi amat pesat begitu mudah untuk diakses dikalangan siswa. Kota kendari ini merupakan ibu kota provinsi yang jauh lebih berkembang dari daerah lainnya di Sulawesi Tenggara. Olehnya itu, penting bagi guru memahami dan memilih model/pendekatan yang digunakan dalam proses pembelajaran terkhusus untuk mengembangkan kemampuan pemecahan masalah matematika siswa dengan menggunakan konteks yang sesuai. 


\section{Kemampuan Pemecahan Masalah Ditinjau dari Tahun Penelitian}

Kemampuan pemecahan masalah matematika melalui meta analisis dilakukan dengan menghitung effect size dengan melihat rata-rata kelas eksperimen $\bar{X}_{E}$, rata-rata kelas kontrol $\bar{X}_{k}$ dan standar deviasi kelas kontrol $S_{K}$. Data hasil penelitian tersebut merupakan hasil penelitian yang dipublikasikan dan yang tidak dipublikasikan dari tahun 2014-2020 yang berada di Universitas Haluoleo Sulawesi Tenggara. Data hasil penelitian yang dianalsis. Nilai effect size kemampuan pemecahan masalah matematika ditinjau dari tahun penelitian dapat dilihat pada tabel 3 berikut.

Tabel 3. Nilai Effect Size Kemampuan Pemecahan Masalah Ditinjau dari Tahun Penelitian

\begin{tabular}{lllllll}
\hline $\begin{array}{l}\text { Kode } \\
\text { Data }\end{array}$ & \multicolumn{1}{c}{ Tahun } & $\overline{\boldsymbol{X}}_{\boldsymbol{E}}$ & $\overline{\boldsymbol{X}}_{\boldsymbol{k}}$ & $\boldsymbol{S}_{\boldsymbol{K}}$ & \multicolumn{1}{c}{$\boldsymbol{\Lambda}$} & Kategori \\
\hline S1 & 2014 & 64,07 & 58,78 & 13,68 & 0,39 & Besar \\
S4 & 2014 & 59,42 & 54,81 & 12,75 & 0,36 & Besar \\
S2 & 2015 & 57,44 & 43,22 & 16,94 & 0,84 & Besar \\
S5 & 2016 & 51,41 & 46,94 & 13,36 & 0,33 & Besar \\
J7 & 2016 & 90,65 & 82,25 & 0,76 & 11,05 & Besar \\
S3 & 2018 & 75,24 & 64 & 10,49 & 1,07 & Besar \\
J2 & 2018 & 44,2 & 29,79 & 10,47 & 1,38 & Besar \\
J5 & 2018 & 73,27 & 59,39 & 11,38 & 1,22 & Besar \\
J8 & 2018 & 58,91 & 55,81 & 23,83 & 0,13 & Sedang \\
S6 & 2019 & 55 & 43,91 & 12,82 & 0,87 & Besar \\
S8 & 2019 & 67,77 & 60,96 & 12,88 & 0,53 & Besar \\
J6 & 2020 & 65,22 & 55,22 & 20,07 & 0,5 & Besar \\
\hline
\end{tabular}

Hasil penelitian tentang kemampuan pemecahan masalah ditinjau dari tahun penelitian diperoleh jumlah terbanyak pada tahun 2018 sejumlah 4 hasil penelitian. Dari hasil analisis effect size taun 2018 menunjukkan 3 hasil penelitian berada pada kategori efek besar dan 1 hasil penelitian berada pada efek sedang. Niai effect size terbesar pada tahun 2018 adalah kode data J2 dengan nilai 1,38 berada pada kategori besar. Pada Tabel 3 nampak nilai effect size tahun 2014, 2015, 2019, dan 2020 berada pada kategori besar.

Pada tahun 2014 terdapat 2 hasil dan keduanya tergolong efek besar. Hasil ini dapat dikatakan bahwa pendekatan Pembelajaran Matematika Realistik efektif digunakan dalam meningkatkan kemampuan pemecahan masalah matematika siswa SMP. Nilai effect size pada tahun 2016 merupakan efek terbesar dan dari dua hasil penelitian tergolong efek besar. Penelitian ini menggunakan model Realistik Matematika Education dan pendekatan metakognisi. Dengan melihat efek ini dapat dikatakan pendekatan Realistik Matematika Education (RME) dan pendekatan metakognisi efektif dapat mengembangkan kemampuan pemecahan masalah matematika siswa.

Tahun 2018 terdapat 4 hasil penelitian tentang kemampuan pemecahan maslah matematika terdiri dari 3 hasil penelitian efek besar dan 1 hasil penelitian efek sedang. Sehingga dapat diketahui bahwa pada tahun 2018 model pembelajaran problem posing efektif digunakan untuk melihat kemampuan pemecahan masalah matematika siswa. Hasil penelitian kemampuan pemecahan masalah matematika pada tahun 2018 tergolong baik sehingga artikel pada tahun 2018 peneliti rekomendasikan untuk dijadikan rujukan untuk peneliti selanjutnya terkhusus pada kemampuan pemecahan masalah matematika. Selanjutnya pada tahun 2019 kemampuan pemecahan masalah juga tergolong efek besar. Model pembelajaran yang digunakan untuk meningkatkan kemampuan pemecahan masalah yaitu model Problem Basic Learning dan Model Kooperatif Tipe Think Talk Write. Sedangkan pada tahun 2020 kemampuan pemecahan masalah siswa pada kategori besar. Nilai ini dikatakan bahwa model Discovery Learning layak digunakan dalam meningkatkan kemampuan pemecahan masalah matematika.

Hasil temuan berdasarkan kategori tahun secara keseluruhan diperoleh nilai rata-rata pada kategori efek besar sehingga kemampuan pemecahan masalah matematika ditinjau dari tahun penelitian memiliki pengaruh yang besar. Bisa dikatakan bahwa kemampuan pemecahan masalah matematika siswa pada dari tahun 20142020 memiliki kemampuan pemecahan masalah matematika yang signifikan. Tetapi, hal ini masih perlu menjadi perhatian serius untuk menggunakan model-model pembelajaran ini agar kemampuan pemecahan masalah matematika siswa bisa terus meningkat dari setiap tahunnya.

\section{Kemampuan Pemecahan Masalah Ditinjau dari Model/ Pendekatan Pembelajaran}


Hasil penelitian tentang kemampuan pemecahan masalah matematika ditinjau dari model/pendekatan pembelajaran dai tahun 2014-2020. Nilai effect size kemampuan pemecahan masalah matematika ditinjau dari tahun penelitian dapat dilihat pada tabel 4 berikut.

Tabel 4. Nilai Effect Size Kemampuan Pemecahan Masalah Ditinjau dari Model/ Pendekatan Pembelajaran

\begin{tabular}{|c|c|c|c|c|c|c|}
\hline $\begin{array}{l}\text { Kode } \\
\text { Data }\end{array}$ & Model/Pendekatan & $\bar{X}_{E}$ & $\bar{X}_{k}$ & $S_{K}$ & $\Lambda$ & Kategori \\
\hline S1 & $\begin{array}{l}\text { Model Realistik Matematika } \\
\text { Education }\end{array}$ & 64,073 & 58,786 & 13,69 & 0,39 & Besar \\
\hline S5 & $\begin{array}{l}\text { Model Realistik Matematika } \\
\text { Education }\end{array}$ & 51,41 & 46,94 & 13,36 & 0,32 & Besar \\
\hline S8 & Model Problem Based Learning & 67,77 & 60,96 & 12,88 & 0,53 & Besar \\
\hline $\mathrm{J} 8$ & Pendekatan Open-Ended & 58,91 & 55,81 & 23,83 & 0,13 & Sedang \\
\hline S4 & Pendekatan Open-Ended & 59,42 & 54,81 & 12,75 & 0,36 & Besar \\
\hline J6 & Model Discovery Learning & 65,217 & 55,217 & 20,069 & 0,5 & Besar \\
\hline $\mathrm{J} 2$ & Model Problem Posing & 44,2 & 29,79 & 10,47 & 1,38 & Besar \\
\hline $\mathrm{J} 5$ & Pendekatan Metakognisi & 73,27 & 59,39 & 11,38 & 1,22 & Besar \\
\hline $\mathrm{J} 7$ & Pendekatan Metakognisi & 90,65 & 82,25 & 0,76 & 11,05 & Besar \\
\hline S3 & Pendekatan Kognitif & 75,24 & 64 & 10,49 & 1,07 & Besar \\
\hline $\mathrm{S} 2$ & Pendekatan Kognitif & 57,44 & 43,22 & 16,94 & 0,84 & Besar \\
\hline S6 & $\begin{array}{l}\text { Model Kooperatif Tipe Think Talk } \\
\text { Write }\end{array}$ & 55 & 43,91 & 12,82 & 0,87 & Besar \\
\hline
\end{tabular}

Hasil analisis effect size pada Tabel 5. tentang kemampuan pemecahan masalah matematika model yang banyak digunakan Model Realistik Matematika Education, Pendekatan Open-Ended, dan Pendekatan Metakognisi. Dari 12 hasil penelitian berada pada kategori efek besar hanya satu hasil penelitian yang tergolong efek sedang yang menggunakan pendekatan Open Ended. Nilai effect size ditinjau dari model pembelajaran yang tergolong efek besar ini menunjukan bahwa model ini efektif dakam mengembangkan kemampuan pemecahan masalah matematika baik siswa SMP maupun siswa SMA. Salah satu hasil penelitian yang mendukung penerapan pendekatan Realistic Mathematic Education adalah penelitian yang dilakukan oleh (Susanti \& Nurfitriyanti, 2018). Hasil penelitiannya mengemukakan model pembelajaran Realistic Mathematic Education berpengaruh terhadap kemampuan pemecahan masalah matematika siswa SMP. Selanjutnya, penelitian (Mayasari, 2019) juga menyatakan pendekatan Open-Eded meningkatkan kemampuan pemecahan masalah matematika siswa.

Model pembelajaran Based Learning juga didukung oleh penelitian (Yusri, 2018) bahwa ada pengaruh model pembelajaran Based Learning terhadap kemampuan pemecahan masalah matematika siswa kelas VII di SMPN 1 Pangkajene. Begitu pula dengan model pembelajaran problem posing sejalan dengan penelitian dilakukan oleh (Ardiyaningrum, 2016) yang menyatakan bahwa model pembelajaran problem posing dapat meningkatkan kemampuan pemecahan masalah matematis kelas VII SMP 9 Muhammadiyah Yogyakarta. Dari hasil penelitian yang sudah ada sebelumnya tentang penggunaan model Realistik Matematika Education, Model Problem Based Learning, dan Model Problem Posing, dapat dikatakan ketiga model ini efektif digunkan dalam upaya mengembangkan dan meningkatkan kemampuan pemecahan masalah matematika pada siswa SMP. Sehingga, model ini bisa menjadi alternatif digunakan dalam pembelajaran matematika pada siswa SMP. Sedangkan pada siswa SMA pendekatan metakognisi lebih efektif penggunaannya dalam pembelajaran matematika agar kemampuan pemecahan masalah matematika siswa bisa berkembang. Sejalan dengan penelitian yang dilakukan oleh Ainuna (Fasha, Johar, \& Ikhsan, 2018) yang menyatakan bahwa kemampuan pemecahan masalah matematika siswa menggunakan pendekatan metakognisi meningkat daripada siswa yang menggunakan pembelajaran konvensional.

Berdasarkan hasil penelitian kemampuan pemecahan masalah matematika siswa melalui meta analisis ini ditinjau dari jenjang pendidikan, wilayah penelitian, tahun penelitian, dan model/pendekatan penelitian secara umum berkembang dengan menerapkan model/ pendekatan yang melibatkan keaktifan siswa dalam pembelajaran. Dalam pembelajaran matematika, kepercayaan diri siswa sehingga ikut terlibat aktif dalam proses pembelajaran berpengaruh terhadap pemecahan masalah (Nugroho dan Dwijayanti, 2019). Selain itu, melihat kemampuan awal matematika siswa dan terus membangkitkan motivasi siswa dalam belajar sangatlah perlu.

\section{KESIMPULAN}

Berdasarkan hasil penelitian ini, maka dapat disimpulkan bahwa kemampuan pemecahan masalah matematika siswa ditinjau dari jenjang pendidikan pada tingkatan SMP lebih cenderung dilakukan pengembangan kemampuan pemecahan masalah dibandingkan pada siswa SMA. Kemampuan pemecahan masalah matematika siswa ditinjau dari wilayah penelitian lebih banyak dilakukan pengembangan di kota 
Kendari daripada di daerah lain, walaupun daerah lain sudah dilakukan penelitian tetapi masih minim. Kemampuan pemecahan masalah matematika siswa ditinjau dari tahun penelitian cenderung tidak stabil setiap tahunnya. Kemampuan pemecahan masalah matematika siswa ditinjau dari model/pendekatan pembelajaranm masih belum maksimal. Dari beberapa hasil penelitia yang telah dianalisis, kemampuan pemecahan masalah matematika dengan penerapan model pada pembelajaran matematika mengalami peningkatan. Faktor yang mempengaruhi kemampuan pemecahan masalah matematika diantaranya kemampuan awal siswa, motivasi, dan pelaksanaan pembelajaran. Pemilihan model/pendekatan pembelajaran yang tepat merupakan alternatif cara memaksimalkan proses pembelajaran dan pengembangan kemampuan berpikir siswa tentang kemampuan pemecahan masalah.

\section{DAFTAR PUSTAKA}

Agus, I. (2019). Efektivitas guided discovery menggunakan pendekatan kontekstual ditinjau dari kemampuan berpikir kritis, prestasi, dan self-efficacy. Jurnal Riset Pendidikan Matematika, 6(2), 120-132. https://doi.org/10.21831/jrpm.v6i2.14517

Anugraheni, I. (2018). Meta Analisis Model Pembelajaran Problem Based Learning dalam Meningkatkan Keterampilan Berpikir Kritis di Sekolah Dasar [A Meta-analysis of Problem-Based Learning Models in Increasing Critical Thinking Skills in Elementary Schools]. Polyglot: Jurnal Ilmiah, 14(1), 9. https://doi.org/10.19166/pji.v14i1.789

Ardiyaningrum, M. (2016). Upaya Peningkatan Kemampuan Pemecahan Masalah Matematis Siswa Kelas Vii Smp Muhammadiyah 9 Yogyakarta Melalui Penerapan Pendekatan Pembelajaran Problem Posing. LITERASI (Jurnal Ilmu Pendidikan). https://doi.org/10.21927/literasi.2013.4(1).53-70

Bishop, C., \& Polya, G. (1991). How to Solve It. The Mathematical Gazette, 75(471), 110. https://doi.org/10.2307/3619013

Fasha, A., Johar, R., \& Ikhsan, M. (2018). Peningkatan Kemampuan Pemecahan Masalah dan Berpikir Kritis Matematis Siswa melalui Pendekatan Metakognitif. Jurnal Didaktik Matematika. https://doi.org/10.24815/jdm.v5i2.11995

Glass. (1982). Meta-analysis in social research. Evaluation and Program Planning. https://doi.org/10.1016/0149-7189(82)90011-8

Hidayat, W., \& Sariningsih, R. (2018). Kemampuan Pemecahan Masalah Matematis dan Adversity Quotient Siswa SMP Melalui Pembelajaran Open Ended. JNPM (Jurnal Nasional Pendidikan Matematika). https://doi.org/10.33603/jnpm.v2i1.1027

Islamiah, N., \& Purwaningsih. (2018). Analisis Hubungan Kemampuan Pemecahan Masalah Matematis. Journal On Education, 1(5), 881-886. https://doi.org/https://doi.org/10.31004/joe.v1i1.10

Kadir, K. (2017). Meta-Analysis of The Effect of Learning Intervention Toward Mathematical Thinking on Research and Publication of Student. TARBIYA: Journal of Education in Muslim Society, 4(2), 162-175. https://doi.org/10.15408/tjems.v4i2.8010

Kurnia, K., Dedyerianto, D., Inah, E. N., \& Patih, T. (2020). Hubungan Minat Belajar dengan Kemampuan Pemecahan Masalah Matematis Siswa Kelas VIII SMP Negeri 6 Buton Tengah. KULIDAWA. https://doi.org/10.31332/kd.v1i1.1813

Liyu, L., Lambertus, L., \& Yasin, M. (2016). Peningkatan Kemampuan Pemahaman dan Pemecahan Masalah Matematik Melalui Pendekatan Metakognisi pada Siswa SMA. ... Pembelajaran Berpikir Matematika (Journal of ..., 1(1), 61-70. https://doi.org/http://dx.doi.org/10.33772/jpbm.v1i1.5418

Mayasari, D. (2019). Pengembangan Bahan Ajar Segitiga Dengan Pendekatan Open Ended Untuk Meningkatkan Kemampuan Pemecahan Masalah Matematika. Jurnal Inovasi Matematika. https://doi.org/10.35438/inomatika.v1i2.151

Nugroho, A. A., \& Dwijayanti, I. (2019). Analisis Kemampuan Pemecahan Masalah Mahasiswa Calon Guru Matematika Pada Mata Kuliah Program Linier. AKSIOMA: Jurnal Matematika dan Pendidikan 
Matematika. https://doi.org/10.26877/aks.v10i2.4720

Nugroho, A. A., Dwijayanti, I., \& Atmoko, P. Y. (2020). Pengaruh Model Pembelajaran Berbasis Penemuan dan Lingkungan Terhadap Kemampuan Pemecahan Masalah Matematika Melalui Meta Analisis. AKSIOMA: Jurnal Program Studi Pendidikan Matematika. https://doi.org/10.24127/ajpm.v9i1.2659

Patih, T., Halistin, H., Sangila, M. S., Agus, I., Dedyerianto, D., Hadi, A. La, .. Samrin, S. (2020). Peningkatan Hasil Belajar Matematika Siswa Menggunakan Model Pembelajaran Berbasis Masalah Berbantuan Multimedia Interaktif. Al-TA'DIB: Jurnal Kajian Ilmu Kependidikan. https://doi.org/10.31332/atdbwv13i2.2330

Rinaldi, E., \& Afriansyah, E. A. (2019). Perbandingan Kemampuan Pemecahan Masalah Matematis Siswa antara Problem Centered Learning dan Problem Based Learning. NUMERICAL: Jurnal Matematika dan Pendidikan Matematika. https://doi.org/10.25217/numerical.v3i1.326

Sangila, M. S., Safaria, S. A., Rahayu, I. R., \& Asran, A. (2019). Penalaran Matematis antara Siswa Laki-Laki dan Perempuan yang Bergaya Kognitif Impulsif dalam Memecahkan Masalah Matematika. Al-TA'DIB. https://doi.org/10.31332/atdb.v12i1.1201

Setiawan, R. H., \& Harta, I. (2014). Pengaruh Pendekatan Open-Ended dan Pendekatan Kontekstual Terhadap Kemampuan Pemecahan Masalah dan Sikap Siswa Terhadap Matematika. Jurnal Riset Pendidikan Matematika, 1(2), 241. https://doi.org/10.21831/jrpm.v1i2.2679

Susanti, S., \& Nurfitriyanti, M. (2018). Pengaruh Model Realistic Mathematics Education (RME) Terhadap Kemampuan Pemecahan Masalah Matematika Pada Siswa Kelas VII SMPN 154 Jakarta. JKPM (Jurnal Kajian Pendidikan Matematika), 3(2), 115. https://doi.org/10.30998/jkpm.v3i2.2260

Yusri, A. Y. (2018). Pengaruh Model Pembelajaran Problem Based Learning Terhadap Kemampuan Pemecahan Masalah Matematika Siswa Kelas VII di SMP Negeri Pangkajene. Mosharafa: Jurnal Pendidikan Matematika, 7(1), 51-62. https://doi.org/10.31980/mosharafa.v7i1.341

Zaif, A., Sunardi, \& Diah, N. (2013). Penerapan Pembelajaran Pemecahan Masalah Model Polya Untuk Menyelesaikan Soal-Soal Pemecahan Masalah Pada Siswa Kelas IX 1 SMP Negeri 1 Jember Semester Ganjil Tahun Ajaran 2012/2013. Pancaran. 